Journal of Physical Education (JouPE)
Vol. 1, No. 2, December 2020, Hal 1-5
E-ISSN: 2723-4746

\title{
Tingkat Daya Tahan Jantung Paru Mahasiswa Olahraga Angkatan 2019 Selama Pandemi Covid
}

\author{
Dwi Handoko $^{1}$, Eko Bagus Fahrizqi ${ }^{2}$, Rizki Yuliandra ${ }^{3}$ \\ Universitas Teknokrat Indonesia ${ }^{\mathbf{1 , 2 , 3}}$ \\ dhandoko611@gmail.com@gmail.com ${ }^{1}$ \\ eko.bagus@teknokrat.ac.id ${ }^{2}$ \\ rizki.yuliandra@teknokrat.ac.id ${ }^{3}$
}

Received: 13 Desember 2020

Accepted: 19 Desember 2020

Published : 29 Desember 2020

\begin{abstract}
Everyone must have the ability to endure the heart and lungs of the body, especially for activities in physical activities. For sports students, the ability of heart and lung endurance is an important asset in carrying out activities, not only to support activities in lectures but also to support activities outside of lectures. This study aims to measure the level of cardiovascular endurance. Tests and measurements were carried out using the $1.2 \mathrm{~km}$ running test. The sample to be studied is sports education students class 2019, Indonesian technocrat University. This research is a survey analysis research using descriptive statistics. From the results of data collection, it was found that 5 students with a percentage of $6.41 \%$ had very good heart and lung levels. Students with the ability of heartlung level who were classified into good categories were 23 students with a percentage of 29, 48\%. Classification of pulmonary heart rate in the medium category was 48 students with a percentage of $62.54 \%$. Thus, the level of cardiovascular endurance of sports education students class of 2019 is classified as moderate.
\end{abstract}

Keywords: Endurance, Heart, Lungs

\begin{abstract}
Abstrak
Kemampuan daya tahan jantung paru pada tubuh harus dimiliki setiap seseorang, khususnya untuk aktivitas dalam kegiatan jasmani. Bagi mahasiswa olahraga kemampuan daya tahan jantung paru menjadi modal penting dalam melakukan kegiatan, tidak hanya untuk mendukung aktivitas pada perkuliahan tetapi juga dalam mendukung dalam aktivitas diluar perkuliahan. Penelitian ini bertujuan untuk mengukur tingkat daya tahan jantung paru. Tes dan pengukuran dilakukan dengan menggunakan tes lari $1,2 \mathrm{~km}$. Sample yang akan diteliti ialah mahasiswa pendidikan olahraga angkatan 2019 Universitas teknokrat Indonesia. penelitian ini merupakan penelitian analisis survei dengan menggunakan deskriptif statistik. Dari hasil pengumpulan data didapatkan hasil yang menunjukkan sebanyak 5 mahasiswa dengan persentase sebanyak 6,41\% memiliki tingkat jantung paru baik sekali. Mahasiswa dengan kemampuan tingkat jantung paru yang diklasifikasikan kedalam kategori baik sebanyak 23 mahasiswa dengan persentase sebesar 29, $48 \%$. Klasifikasi tingkat jantung paru dengan kategori sedang sebanyak 48 mahasiswa dengan persentase sebesar $62,54 \%$. Dengan demikian maka tingkat daya tahan jantung paru mahasiswa pendidikan olahraga angkatan 2019 masuk ke klasifikasi Sedang.
\end{abstract}

Kata Kunci: Daya Tahan, Jantung, Paru

\section{To cite this article:}

Handoko, Dwi., Fahrizqi, Eko Bagus \& Yuliandra, Rizki. (2020). Tingkat Daya Tahan Jantung Paru Mahasiswa Olahraga Angkatan 2019 Selama Pandemi Covid. Journal of Physical Education. Vol 1, No (2), Hal 1-5 


\section{PENDAHULUAN}

Kondisi seseorang dalam hal kebugaran jasmani dapat beradaptasi dengan segala beban fisik ataupun psiskis yang dialami seseorang, itu adalah dasar untuk mencapai produktifitas maupun prestasi kerja yang optimal. Menurut (Hartono, 2013) kebugaran jasmani adalah suatu kemampuan dari seseorang untuk melakukan bentuk tugas, pekerjaan serta rutinitas sehari hari dengan kemapuan fisik prima, tidak mengalami suatu kelelahan yang berat setelah melakukan kegiatan aktivitas. Kebugaran jasmani perlu untuk ditingkatkan dan dijaga. Pada dasarnya meningkatkan dan menjaga kebugaran jasmani yang teratur dan sistematis merupakan bagian dari pola hidup yang terus berkembang. Menerapkan hidup aktif dan sehat merupakan strategi untuk meningkatkan kebugaran jasmani. Untuk menerapkan jenis kegiatan yang tepat dalam program hidup aktif dan sehat dapat disesuaikan dengan tingkat kebugaran jasmani (Sulistiono, 2014). Bagi seorang atlet olahraga guna mencapai prestasi tidak hanya memiliki level kebugaran jasmani saja, namun jug harus memiliki kemampuan biomotor (Qutoriki Rohmah \& Purnomo, 2018). Kebugaran jasmani yang memadai, paling tidak menguasai salah satu nomor olahraga dan olahraga permainan sehingga nantinya peserta didik diharapkan mempunyai kepercayaan diri untuk melakukan kegiatan dalam olahraga yang teratur dan aktif karena didukung dengan pengetahuan yang memadai mengenai ilmu pendidikan jasmani dan olahraga (Yuliandra \& Fahrizqi, 2019).

Daya tahan jantung paru ialah kondisi tubuh yang mampu melakukan aktivitas dengan waktu yang lama,tanpa mengalami kelelahan yang berlebihan. Kebutuhan gizi dan makan harus diperhatikan untuk sumber energi,pembangunan sel-sel tubuh dan metabolisme makanan harus sesuai dengan tubuh, faktor tersebut berpengaruh untuk memperoleh tingkat daya tahan jantung dan pernafasan yang baik. Proses memulihkan tubuh untuk tumbuh dan berkembang serta melakukan kegiatan fisik sehari-hari sangat memerlukan zat gizi,tingkat daya tahan jantung dan pernafasan dapat dipengaruhi dengan faktor usia,jenis kelamin,kegiatan olahraga,aktifitas bermain,sarana dan prasarana,lingkungan yang bersih dan nyaman. Latihan untuk meningkatkan daya tahan jantung dan pernafasan ialah latihan yang berlangsung lama seperti lari jarak jauh,renang jarak jauh,cross country atau lari lintas alam,interval training,fartlek,atau bentuk latihan yang bersifat memaksa tubuh kita untuk bekerja dengan waktu yang lama.(Zulbahri, 2019).Untuk meningkatkan level kapasitas vital paru beberapa latihan fisik harus dilakukan oleh seorang atlet, agar peningkatan level kapasitas VO2max terwujud secara maksimal sebaiknya latihan yang dilakukan adalah program latihan aerobic (Gumantan \& Fahrizqi, 2020). Kemampuan aerobik merupakan kemampuan dari olah daya aerobik terbesar yang dimiliki oleh seseorang atlet. (Gumantan \& Fahrizqi, 2020). Hal ini dapat dlihat dan ditentukan berdasarjumlah oksigen (O2) yang masuk dan dipasok ke jantung, kemudian dialirkan ke bagian pernapasan melalui paru, dan pengaruh kadar nutrisi pada setiap menitnya (Gumantan \& Fahrizqi, 2020).Menurut (Sukadiyanto \& Muluk, 2011) Peningkatan kapasitas level VO2max akan menjadi lebih tinggi dimulai dari umur 10 tahun, walau ada pendapat lain tentang latihan ketahanan tidak berpengaruh pada kemampuan aerobik terutama saat usia 11 tahun. Gambaran secara umumnya, suatu kemampuan aerobik turun perlahan setelah memasuki usia pada 25 tahun (Sukadiyanto \& Muluk, 2011).

Saat ini sedang terjadi bencana corona virus-19. Kejadian ini oleh organisasi kesehatan dunia (WHO) sendiri dinyatakan sebagai sebuah pendemi global (Susmiati, 2020). Bencana yang dikategorikan non alam ini memaksa seluruh dunia masuk ke dalam tatanan social yang baru, termasuk berdampak juga ke dunia pendidikan, dengan kebijakan physical distancing dengan melarang seluruh peserta didik untuk belajar di sekolah atau universitas, ini merupakan tantangan besar untuk dihadapi semua pengajar (Susmiati, 2020). Oleh karena itu kata sosial diganti dengan kata fisik dengan tujuan setiap orang tetap bisa berinteraksi namun dengan menjaga jarak setidaknya satu meter (Gumantan, Mahfud, \& Yuliandra, 2020). Dengan kondisi yang seperti ini , proses pembelajaran tetap harus berlangsung guna mencapai target kompetensi yang ingin dicapai, salah satunyadengan pembelajaran di rumah dengan sistem daring (dalam jaringan) (Susmiati, 2020). Oleh sebab itu kondisi fisik dan daya tahan mahasiswa pendidikan olahraga perlu diperhatikan. Seluruh mahasiswa UTI termasuk mahasiswa pendidikan olahraga melaksanakan perkuliahan full daring dikarenakan masih dalam masa Pandemi Covid 19. Situasi seperti saat ini membuat perkuliahan serta aktivitas kampus terbatas,sehingga perkuliahan praktek atau dilapangan dilakukan secara daring dengan menggunakan video pembelajaran. Seluruh mahasiswa UTI mengharapkan Pandemi Covid 19 segera berakhir agar dapat melaksanakan perkuliahan dan aktivitas dapat berjalan seperti semula. Tidak hanya dari segi pembelajaran tapi dari segi aktivitas fisik juga mengalami hal yang sama. Pentingnya memperhatikan kondisi fisik serta tingkat daya tahan jantung paru untuk 
mahasiswa pendidikan olahraga, karena perkuliahan yang dilakukan hampir sebagian besar dilakukan di lapangan. Dan pastinya harus memiliki kondisi fisik serta daya tahan yang baik. Sebagai mahasiswa pendidikan olahraga perlu meningkatkan kondisi fisik serta daya tahan, hal ini merupakan faktor yang paling mendasar untuk melakukan rutinitas sebagai mahasiswa. Menjaga kebugaran jasmani dan daya tahan tubuh tentunya harus dilakukan dengan rutin berolahraga. Karena olahraga merupakan salah satu media fisik untuk membuat dan menjadikan kondisi kesehatan dari manusia menjadi lebih baik dan lebih terjaga (Rahadian, 2019). Jadi dapat disimpulkan bahwa penelitian dilakukan untuk mengetahui perbandingan tingkat daya tahan jantung paru mahasiswa pendidikan olahraga angkatan 2019 selama pandemic covid 19.

\section{METODE PENELITIAN}

\section{Populasi dan Sampel}

Populasi dan Sampel pada penelitian adalah mahasiswa pendidikan olahraga angkatan 2019 Universitas Teknokrat Indonesia kelas A sebanyakan 41 Mahasiswa dan Kelas B Sebanyak 37. Dengan keseluruhan jumlah populasi dan sampel total sebanyak 78 Mahasiswa karena sampel kurang dari 100.

\section{Teknik Pengumpulan Data}

Metode riset penelitian menggunakan metode deskriptif statistik serta pengumpulan data penelitian dengan memakai tes pengukuran. Data yang diperoleh untuk penelitian melalui tes pengukuran adalah dengan tes daya tahan aerobik/tes jantung paru.

\section{Metode Analisis}

Untuk memeproleh hasil akhir analisis data, maka data yang diperoleh dari pengumpulan data perlu diubah dalam satuan skor. Untuk perolehan skor tersebut dipakai untuk dasar pendataan penentuan tingkat daya tahan jantung dan paru. Penentuan hasil dilihat dari tabel klasifikasi tes daya tahan jantung dan paru

\section{Variabel Operasional} (VO2Max).

Dalam penelitian ini yang menjadi variabelnya yakni komponen kondisi fisik yaitu daya tahan aerobik

\section{HASIL DAN PEMBAHASAN}

Dari hasil analisa data yang diperoleh melalui pemgumpulan data, maka diperoleh beberapa hasil dari analisis data yang berupa uji normalitas data dan hasil dari tes pengukuran terhadap daya tahan jantung paru. Dibawah ini penjelasan mengenai tabel distribusi uji normalitas data :

Table 1. Tabel Uji Normalitas data

Tests of Normality Daya Tahan Jantung Paru

\begin{tabular}{|c|c|c|c|c|c|c|}
\hline & \multicolumn{3}{|c|}{ Kolmogorov-Smirnov $^{\mathrm{a}}$} & \multicolumn{3}{c|}{ Shapiro-Wilk } \\
\cline { 2 - 7 } & Statistic & $\mathrm{df}$ & Sig. & Statistic & df & Sig. \\
\hline KelasA &, 261 & 39 &, 000 &, 852 & 39 &, 000 \\
KelasB &, 487 & 37 &, 000 &, 497 & 39 &, 000 \\
\hline
\end{tabular}

a. Lilliefors Significance Correction

Table 2. Tabel Uji Non Parametrik Data Tests of Normality

\begin{tabular}{|c|c|c|c|c|c|c|}
\hline & \multicolumn{3}{|c|}{ Kolmogorov-Smirnov $^{\mathrm{a}}$} & \multicolumn{3}{|c|}{ Shapiro-Wilk } \\
\hline & Statistic & df & Sig. & Statistic & df & Sig. \\
\hline KelasAB & ,370 & 78 & ,000 & ,748 & 78 & ,000 \\
\hline
\end{tabular}

a. Lilliefors Significance Correction

Berdasar hasil uji normalitas pada tes daya tahan jantung paru kelas A dan Kelas B dengan menggunakan program statistik SPSS didapatkan nilai sig pada tabel kolmogorov-smirnov yakni sebesar $0,000<\alpha 0,05$. Dengan demikian untuk uji normalitas karena nilai sig tidak lebih besar daripada nilai alpa makan akan diujikan dengan menggunakan tes non parametrik. Untuk nilainya harus lebih kecil dari 0,050 dengan perbedaan 2 rata-rata dengan nilai $0,000^{1}$. 
Tabel 2. Klasifikasi Tingkat Jantung Paru dengan Tes Lari 1,2 Km

\begin{tabular}{ccclcc}
\hline No & Skor & Nilai & \multicolumn{1}{c}{ Klasifikasi } & Frekuensi & Presentase \% \\
\hline 1 & Sd $-\mathbf{3 , 1 4} "$ & 5 & Baik Sekali (BS) & 5 & $6,41 \%$ \\
\hline 2 & $3,15 "-4,25 ”$ & 4 & Baik (B) & 23 & $29,48 \%$ \\
\hline 3 & $4,26 "-5,12 ”$ & 3 & Sedang (S) & 48 & $61,54 \%$ \\
\hline 4 & $5,13 "-6,33 "$ & 2 & Kurang (K) & 2 & $2,56 \%$ \\
\hline 5 & $\mathbf{6 , 3 4}$ dst & 1 & Kurang Sekali (KS) & 0 & $0 \%$ \\
\hline & & & Total & $\mathbf{7 8}$ & $\mathbf{1 0 0 \%}$ \\
\hline
\end{tabular}

Dari hasil rekap data dan penghitungan tes daya tahan jantung paru dengan menggunakan tes lari $1,2 \mathrm{~km}$ didapatkan hasil klasifikasi untuk mahasiswa angkatan 2019. Berdasarkan klasifikasi dari total keseluruhan mahasiswa angkatan 2019 yang berjumlah 78 mahasiswa sebanyak 5 mahasiswa dengan persentase sebanyak $6,41 \%$ memiliki tingkat jantung paru baik sekali. Mahasiswa dengan kemampuan tingkat jantung paru yang diklasifikasikan kedalam kategori baik sebanyak 23 mahasiswa dengan persentase sebesar 29, $48 \%$. Klasifikasi tingkat jantung paru dengan kategori sedang sebanyak 48 mahasiswa dengan persentase sebesar $62,54 \%$. Dan mahasiswa dengan klasfikasi tingkat jantung paru yang dikategorikan kurang berjumlah 2 mahasiswa dari total keseluruhan jumlah mahasiswa pendidikan olahraga angkatan 2019, dan tidak ada mahasiswa dengan tingkat klasifikasi jantung paru yang dikategorikan kurang sekali. Tes dan pengukuran lari 1,2 $\mathrm{Km}$ digunakan untuk mengetahi tingkat daya tahan jantung dan paru-paru, frekuensi pernafasan dan sistem kardiovaskuler dalam tubuh. Pada tes lari 1,2 km ini, alat yang digunakan adalah stopwatch, lintasan untuk lari, peluit, bendera dan alat pencatat skor.

\section{SIMPULAN}

Dari hasil tes pengukuran tingkat jantung paru yagn telah dilakukan pada mahasiswa pendidikan olahraga 2019 selama pandemi covid 2019. Klasifikasi tingkat jantung paru menunjukkan pada hasil pada klasifikasi sedang. Selama pandemi mahasiswa khususnya mahasiswa olahraga harusnya lebih banyak melakukan aktivitas jasmani. Dimana aktivitas tersebut diperlukan guna menjaga kebugaran serta menjaga kondisi tubuh agar tetap bugar tidak hanya selama terjadinya pandemi tetapi juga untuk seterusnya. Kebugaran jasmani yang baik tentunya ditopang dengan tingkat jantung paru yang baik. Secara tidak langsung komponen daya tahan jantung paru mempunyai dampak langsung terhadap kebugaran jasmani karena menjadi komponen utama dalam tingkat daya tahan tubuh melawan keletihan.

Tingkat daya tahan jantung paru menjadi kemampuan yang harus dimiliki setiap orang khususnya yang berhubungan dengan aktivitas olahraga. Secara anatomis tingkat daya tahan jantung paru yang baik dapat diartikan kelancaran sistem peredaran darah pada tubuh. Pada saat melakukan aktivitas olahraga dengan intensitas yang rendah, ketersediaan oksigen dalam tubuh masih reltif cukup besar, sistem pada molekul asam piruvat yang terbentuk akan diubah menjadi karbondioksida. Namun Jika ketersediaan pasokan oksigen dalm tubuh dalam kategori terbatas, maka pembentukan asam piruvat akan terjadi begitu cepat maka asam piruvat tersebut akan terkonversi dan diubah menjadi asam laktat. Asam laktat merupakan sisa-sisa pembuangan yang tidak bisa dikonversi menjadi energi. Dimana bila terjadi penumpukan asam laktat ini akan mengakibatkan kelelahan pada sistem muskulo, dan dari sistem muskulo kemudian masuk kesistem jantung paru.

Bila kemampuan jantung paru yang miliki seseorang dikategorikan sangat baik, maka artinya pada saat seseorang tersebut melakukan aktivitas atau kegiatan jasmani yang berat maka tidak akan terlalu berdampak pada komponen jasmani yang lainnya. Karena dengan mempunyai komponen Kebugaran jasmani yangbaik khusunya pada komponen daya tahan , maka seseorang dapat menjalankan aktivitas dengan efektif dan efisien tanpa akan menimbulkan kelelahan. Artinya setelah melakukan aktivitas olahraga maka seseoang akan tetap dapat melakukan aktivitas lainnya setelah melakukan jeda beristirahat. Untuk mahasiswa olahraga sendiri, dengan kemampuan jantung paru yang baik, maka dia dapat melakukan aktivitas khususnya diluar perkuliahan tanpa mengalami kelelahan. Artinya mahasiswa dapat melakukan kegiatan diluar tanggungan perkuliahn, dimana banyak mata kuliah yang diharuskan melakukan aktivitas fisik, walaupun saat ini kegiatan perkuliahan masih menggunakan sistem online. Walaupun menggunakan daring tetap tidak menghilangkan aktivitas kebugaran jasmani yang akan menjadi modal utama dalam dunia pendidikan olahraga. 


\section{DAFTAR PUSTAKA}

Gumantan, A., \& Fahrizqi, E. B. (2020). Pengaruh Latihan Fartlek dan Cross Country Terhadap Vo2Max Atlet Futsal Universitas Teknokrat Indonesia. SPORT-Mu: Jurnal Pendidikan Olahraga, 1(01), 1-9.

Gumantan, A., Mahfud, I., \& Yuliandra, R. (2020). Tingkat Kecemasan Seseorang Terhadap PEmberlakuan New Normal dan Pengetahuan Terhadap Imunitas Tubuh. Sport Science And Education Journal, 1(2).

Hartono, S. (2013). Pendidikan Jasmani (Sebuah Pengantar). Surabaya: Unesa University Press.

Qutoriki Rohmah, M., \& Purnomo, M. (2018). Pengaruh latihan chest press resistance band dan push up terhadap kekuatan otot lengan mahasiswa Universitas Negeri Surabaya. Jurnal Prestasi Olahraga, 1(4), 116.

Rahadian, A. (2019). Aplikasi Analisis Biomekanika (Kinovea Software) Untuk Mengembangkan Kemampuan Lari Jarak Pendek (100 M) Mahasiswa PJKR Unsur. Journal of SPORT, 3(1), 1-8.

Sukadiyanto \& Muluk, D. (2011). Pengantar teori dan metodologi melatih fisik. In Bandung: Lubuk Agung. Bandung: CV Lubuk Agung.

Sulistiono, A. A. (2014). Di Jawa Barat Basic and Secondary Education Students Physical Fitness. Jurnal Pendidikan dan Kebudayaan, 20 no 2, 223-233.

Susmiati, E. (2020). Meningkatkan Motivasi Belajar Bahasa Indonesia Melalui Penerapan Model Discovery Learning dan Media Video Dalam Kondisi Pandemi Covid-19 bagi Siswa SMPN 2 Gangga. Jurnal Paedagogy, 7(3), 210-215.

Yuliandra, R., \& Fahrizqi, E. B. (2019). Pengembangan Model Latihan Jump Shoot Bola Basket. Journal of SPORT, 3(1), 51-55.

Zulbahri. (2019). Tingkat Kemampuan Daya Tahan Jantung Dan Pernafasan Mahasiswa Pendidikan Olahraga Dan Kesehatan Universitas Pasir Pengaraian. 3, 96-101.

\section{BIOGRAFI PENULIS}
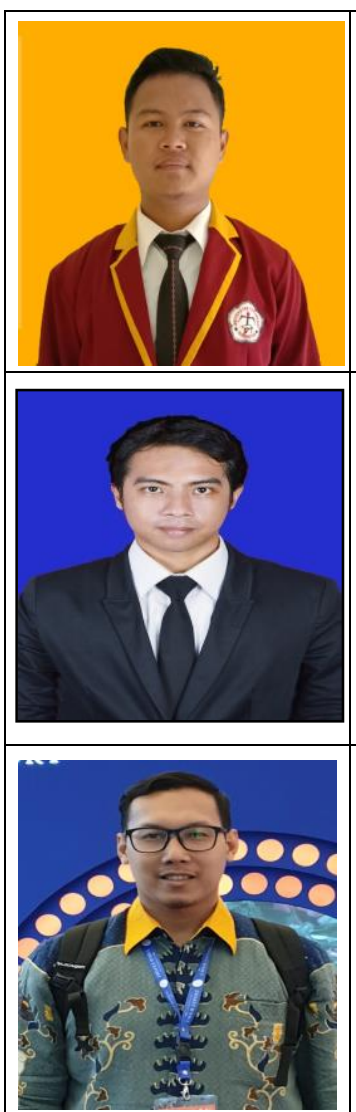

Dwi Handoko

Lahir di Setia Negara, 19 Juli 1999, Desa Setia Negara, Kecamatan Baradatu Kabupaten Way Kanan. Penulis menyelesaikan Pendidikan Sekolah Menengah Atas di SMAN 1 Baradatu, saat ini sedang menempuh pendidikan Program Sarjana (Strata -1) pada Fakultas Sastra dan Ilmu Pendidikan dengan Program Studi Pendidikan Olahraga. Penulis juga sebagai Asisten pengajar pada Universitas Teknokrat Indonesia pada Program Studi Pendidikan Olahraga. Penulis dapat dihubungi melalui email: dhandoko611@gmail.com

\section{Eko Bagus Fahrizqi, M.Pd,}

Lahir Gedong Tataan, 17 Agustus 1991, Kabupaten Pesawaran, Menyelesaikan pendidikan Program Sarjana (Strata -1) pada Fakultas Keguruan dan Ilmu Pendidikan dengan Program Studi Pendidikan Jasmani dan Kesehatan (2009-2013), dan melanjutkan Program Pascasarjana Magister Pendidikan (Strata-2) pada Program Pasca Sarjana Universitas Negeri Jakarta dengan mengambil Program Studi Pendidikan Olahraga (2013-2015). Penulis juga sebagai pengajar pada Universitas Teknokrat Indonesia pada Program Studi Pendidikan Olahraga (2016Sekarang). Penulis dapat dihubungi melalui email: eko.bagus@teknokrat.ac.id

\section{Rizki Yuliandra, M.Pd.}

Menyelesaikan pendidikan Program Sarjana (Strata -1) pada Fakultas Keguruan dan Ilmu Pendidikan dengan Program Studi Pendidikan Jasmani dan Kesehatan (2009-2013) di Universitas Lampung, kemudian melanjutkan Program Pascasarjana Magister Pendidikan (Strata-2) pada Program Pasca Sarjana Universitas Negeri Jakarta dengan mengambil Program Studi Pendidikan Olahraga (2013-2015). Menjabat Wakil Dekan 3 Fakultas Sastra dan Ilmu Pendidikan serta pengajar pada pada Program Studi Pendidikan Olahraga (2016-Sekarang). Penulis dapat dihubungi melalui email: rizki.yuliandra@teknokrat.ac.id 